\title{
Penerapan prinsip DIR/Floortime Meningkatkan Kemampuan Memusatkan Atensi pada Anak dengan ADHD
}

\author{
Ratih Larasati, Lia M. Boediman, Mita Aswanti \\ Magister Profesi Psikologi Klinis Anak, Fakultas Psikologi, Universitas Indonesia, \\ ratih.larasati@yahoo.co.uk
}

\begin{abstract}
Developmental, Individual Differences, Relationship-Based approach (DIR/Floortime) is one of the available interventions focused on increasing the quality of caregiver-child interaction. This study is aimed at investigating the effectiveness of DIR/Floortime to increase the ability to sustain attention on a 4 year-old child with Early Onset Attention-Deficit/Hyperactivity Disorder (ADHD). This is a qualitative research involving two participants, a boy diagnosed with ADHD, and the mother of the boy. This research utilized observation and interview in gathering the data, accompanying the use of observation log for duration of attention and frequency of distractedness specifically designed for this research, Functional Emotional Assessment Scale (FEAS), questionnaire and interview guideline: Observing Child's Biological Challenge (OCBC), and Sensory Processing Motor Planning Questionnaire (SPMPQ). The result of this study indicated that the application of DIR/Floortime principles is effective in increasing the ability to sustain attention on a 4 year-old child with Early Onset ADHD, along with the increase of the functional emotional development of both mother and child as shown with the increase of attention span, the decrease of frequency of distractibility, and score increase in the Functional Emotional Assessment Scale (FEAS).
\end{abstract}

Key words: DIR/Floortime, Attention span, Functional emotional development

Abstrak. Pendekatan Developmental, Individual Differences, Relationship-Based (DIR/Floortime) merupakan salah satu program intervensi yang difokuskan untuk meningkatkan kualitas interaksi antara pengasuh utama dan anak. Penelitian ini bertujuan untuk meninjau efektivitas penerapan prinsip DIR/Floortime untuk meningkatkan kemampuan memusatkan atensi pada anak berusia 4 tahun yang memiliki diagnosa Early Onset AttentionDeficit/Hyperactivity Disorder (ADHD). Penelitian ini merupakan penelitian kualitatif dengan dua partisipan, seorang anak laki-laki dengan diagnosa ADHD, dan ibu dari anak tersebut. Penelitian ini melibatkan observasi dan wawancara dengan alat ukur: tabel pencatatan observasi durasi memusatkan atensi dan frekuensi distraktibilitas yang diciptakan khusus untuk penelitian ini, Functional Emotional Assessment Scale (FEAS), serta kuesioner dan panduan wawancara Observing Child's Biological Challenge (OCBC) dan Sensory Processing - Motor Planning Questionnaire (SPMPQ). Hasil penelitian ini menunjukkan bahwa penerapan prinsip DIR/Floortime efektif meningkatkan kemampuan memusatkan atensi pada anak dengan Early Onset ADHD serta diiringi dengan peningkatan tahapan perkembangan fungsional emosional anak dan ibu yang terukur dari peningkatan durasi memusatkan atensi, penurunan frekuensi distraktibilitas, serta peningkatan skor pada Functional Emotional Assessment Scale (FEAS).

Kata Kunci: DIR/Floortime, Rentang atensi, Perkembangan emosional fungsional 
Kemampuan belajar merupakan kemampuan yang harus dimiliki setiap anak dan perlu diasah sejak dini. Kemampuan belajar mencakup kemampuan akademis, kemampuan memahami pengalaman dari lingkungan, serta kemampuan mengambil manfaat dari pengalaman tersebut (Bradway \& Hill, 2004). Kemampuan anak untuk menerima informasi dan mengevaluasi situasi lingkungan sekitar merupakan fondasi dari kemampuan belajar (Bradway \& Hill, 2004).

Bradway dan Hill (2004) kemudian menjelaskan bahwa kemampuan belajar anak sangat dipengaruhi oleh kemampuan mereka dalam memusatkan perhatian, juga kemampuan untuk mempertahankan keadaan diri dalam kondisi tenang dan sadar akan lingkungannya. Oleh karena itu, anak yang memiliki masalah dalam memusatkan atensi akan sulit untuk memfokuskan diri dan menarik informasi dari lingkungan sekitar (Bradway \& Hill, 2004). Kondisi demikian dapat menghambat perkembangan kemampuan belajarnya (Greenspan \& Greenspan, 2009).

Lebih jauh, Greenspan dan Greenspan (2009) menjelaskan bahwa anakanak dengan masalah atensi memiliki kesulitan dalam memahami instruksi verbal, menaati aturan, mengenali lingkungannya, dan melihat diri mereka dalam konteks lingkungannya. Selain itu, mereka juga memiliki hambatan dalam mengorganisasi informasi dan memahami apa yang mereka lihat atau dengar. Kesulitan-kesulitan tersebut akan menghambat perkembangan kemampuan belajar serta pencapaian akademis mereka di kemudian hari.

Masalah terkait perhatian tersebut biasa ditemui pada anak dengan AttentionDeficit/Hyperactivity Disorder (ADHD). Mash dan Wolfe (2010) menjelaskan bahwa kebanyakan anak ADHD memiliki setidaknya tingkat inteligensi rata-rata, bahkan beberapa memiliki tingkat inteligensi di atas rata-rata. Kesulitan mereka muncul bukan dalam rendahnya taraf inteligensi, namun dalam mengaplikasikan pengetahuan yang mereka miliki dalam kehidupan, sehingga anak tidak dapat hidup sesuai dengan potensinya (Barkley 2006). Seringkali, hambatan dalam kemampuan akademis ini muncul karena ketidakmampuan mereka dalam memusatkan perhatian, dan karakteristik hiperaktivitas-impulsivitas mereka yang memengaruhi proses pembelajaran (Biederman, Monuteaux, Doyle, Seidman, Wilens, Ferrero, Morgan, \& Faraone, 2004).

ADHD adalah label diagnostik yang digunakan untuk anak-anak yang menunjukkan masalah signifikan dalam atensi, impulsivitas dan hiperaktivitas (Barkley, 2006). Anak yang memiliki ADHD biasanya nampak oleh orang lain sebagai anak yang memiliki kesulitan kronis untuk memusatkan perhatian, dan menunjukkan hiperaktivitas dan impulsivitas (Barkley, 2006). Konsensus saat ini mengenai pendapat para ahli adalah bahwa sekitar 37 persen dari populasi anak usia sekolah di dunia memiliki ADHD (American Psychiatric Association, 2000). Di Indonesia, menurut Pusponegoro (Mediaindo.co.id, 2004), sebanyak 5 persen anak Indonesia memiliki ADHD. Selain itu, penelitian yang dilakukan oleh Dwijo Saputro di Yogyakarta menyebutkan bahwa terdapat sebanyak 28,1 persen anak sekolah di Yogyakarta mengalami ADHD, dengan perbandingan anak laki-laki dan perempuan antara 4:1 hingga 9:1 (Mediaindo.co.id, 2004).

Greenspan dan Greenspan (2009) menyatakan bahwa ada dua faktor yang dapat menyebabkan gejala-gejala hiperaktivitas dan impulsivitas yang umumnya disebut sebagai ADHD. Faktor pertama merupakan gangguan dalam 
memodulasi informasi sensoris, seperti perencanaan dan pengurutan gerakan, respon terhadap sensasi atau stimulus, dan perilaku mencari stimulus sensoris (Interdisciplinery Council on Developmental and Learning Disrorder, 2005).

Faktor kedua adalah hambatan dalam pemrosesan stimulus auditorisverbal atau visuo-spasial (Interdisciplinery Council on Developmental and Learning Disrorder, 2005). Contohnya, beberapa anak sangat reaktif terhadap stimulus visual, auditoris, dan sensasi-sensasi sehingga sangat mudah untuk terdistraksi. Ada beberapa anak lainnya yang sangat bertolak pada stimulus visual, auditoris, dan taktil sehingga mereka tampak selalu bergerak dan cepat berpindah dari satu hal ke hal lainnya. Ada juga anak yang sangat tidak reaktif terhadap stimulus visual, auditoris, dan sensasi umum lainnya sehingga membuat mereka tenggelam dalam imajinasi mereka sendiri dan nampak inatentif. Hambatan-hambatan ini membuat anak-anak mengalami kesulitan dalam mengembangkan kemampuan belajar mereka, dan membedakan emosi mereka dan orang lain (Greenspan \& Greenspan, 2009).

Beberapa intervensi dan treatment yang dapat diterapkan pada anak ADHD antara lain farmakoterapi; parental training/counseling, aplikasi pada orang tua atau di situasi kelas; dan terapi perilaku (Pelham, Wheeler, dan Chronis, 1998 dalam Schroeder dan Gordon, 2002). Terapi yang digunakan untuk anak dengan ADHD saat ini umumnya melibatkan beberapa jenis program manajemen perilaku untuk mengatasi perilaku impulsif pada anakanak ini (Greenspan \& Greenspan, 2009). Akan tetapi, program terapi perilaku lebih difokuskan untuk mengatasi gejala (symptom relief) pada umumnya, dan tidak mentargetkan pada alasan mendasar mengapa anak kesulitan untuk memusatkan atensi, fokus, dan mengontrol diri sendiri.

Intervensi yang dibutuhkan untuk anak-anak dengan ADHD adalah intervensi yang didasari oleh pemahaman akan masalah anak dalam memusatkan atensi dan konsekuensinya pada kehidupan sehari-hari, serta pemahaman akan faktor yang dapat ditingkatkan untuk menguatkan fokus dan atensi anak tersebut, seperti kemampuan untuk menerima dan memroses informasi sensoris dari lingkungan (Greenspan \& Greenspan, 2009). Greenspan dan Greenspan (2009) menyimpulkan bahwa program yang dibutuhkan adalah program yang secara sistematis dapat meningkatkan dan menguatkan kemampuan dasar yang dibutuhkan untuk kemampuan belajar, yaitu pemusatan atensi dan regulasi diri, serta kemampuan untuk menerima sehingga pada nantinya anak ini dapat memiliki kemampuan belajar lebih baik.

Salah satu jenis terapi yang sesuai dengan deskripsi di atas adalah penerapan prinsip DIR/Floortime. Prinsip DIR/Floortime difokuskan untuk membangun landasan yang kuat agar anak mampu mengembangkan kapasitas untuk memusatkan atensi. Awalnya prinsip dan pendekatan ini dikembangkan untuk anak dengan Autism Spectrum Disorder (ASD), namun dalam perkembanganny, banyak anak dengan gangguan perkembangan lainnya bisa mendapatkan manfaat dari pendekatan ini (Greenspan \& Wieder, 2006). Hal ini disebabkan oleh prinsipprinsip yang digunakan dalam DIR/floortime, seperti mengikuti petunjuk anak, menyesuaikan diri dengan tahapan perkembangan anak dan profil individual differences yang dimiliki anak, sesuai untuk anak yang memiliki berbagai macam keadaan, misalnya pada anak normal, anak dengan gangguan bahasa, anak dengan 
gangguan perkembangan, dan pada anak yang menyandang ADHD (Greenspan \& Greenspan, 2010).

Prinsip DIR/Floortime ini menganggap bahwa anak dengan gangguan perkembangan tidak menguasai tingkatan-tingkatan awal perkembangan (early developmental milestones) yang menjadi fondasi bagi pembelajaran dikemudian hari. Hal ini disebabkan oleh adanya perbedaan dalam cara memroses informasi pada anak-anak ini (Greenspan \& Wieder, 2006). Dengan menggunakan pendekatan DIR/floortime, pemberian intervensi dapat difokuskan untuk meningkatkan kemampuan anak dalam memusatkan atensi dan menyesuaikan pendekatan dengan karakteristik unik masing-masing anak atau profil biologisnya (masalah sensorisnya), yang merupakan fondasi dari kemampuan belajar.

Penelitian ini dilakukan dengan tujuan untuk melihat efektivitas penerapan DIR/Floortime pada anak ADHD dan orang tua dengan anak ADHD. Pada anak ADHD, penelitian ini berfokus kepada apakah DIR/floor mampu meningkatkan kemampuan pemusatan atensi, kemampuan mempertahankan konsentrasi dan perkembangan fungsional emosional mereka. Penelitian ini juga melihat apakah DIR/floor dapat meningkatkan perkembangan fungsional emosional ibu dan interaksi mereka dengan anak mereka yang mengalami ADHD.

Pendekatan DIR/floortime meninjau ADHD sebagai suatu gangguan yang memiliki akar permasalahan pada sensory regulation dan hambatan perkembangan executive functioning (Greenspan \& Greenspan, 2009). Masalah dalam sensory regulation dapat berupa mencari stimulus sensoris (sensory-seeking), atau menghindari stimulus sensoris (sensory-avoidant) (Barkley, 2006).
Menurut Greenspan dan Greenspan (2009), anak-anak dengan ADHD cenderung masuk ke dalam kategori sensory-seeking. Mereka bisa nampak underreactive ataupun overreactive, namun secara konstan mereka akan mencari stimulus seperti sentuhan, suara, dan banyak pergerakan, sehingga mereka akan menjadi sangat aktif, mudah terdistraksi, dan inatentif. Hal ini konsisten dengan pendapat Yochmn, Parush, dan Ornoy (2004) yang mengemukakan bahwa bahwa anak-anak dengan ADHD umumnya mengalami defisit dalam pengolahan sensorik, terutama disfungsi modulasi sensorik. Penelitian ini menunjukkan bahwa anak dengan ADHD memiliki gangguan dalam penerimaan dan pengolahan informasi sensorik, yang memengaruhi anak dalam lingkungan di sekitar mereka seperti rumah, sekolah, dan masyarakat.

Etiologi ADHD berdasarkan pendekatan DIR/Floortime dapat dijelaskan melalui teori the learning tree. Dalam teori ini, Greenspan dan Greenspan (2010) menggunakan metafora sebuah pohon untuk menggambarkan perkembangan seorang anak. Greenspan dan Greenspan (2010) juga menyatakan bahwa sebuah pohon dapat berkembang menjadi pohon yang sehat, memiliki cabang yang banyak, dan daun yang subur, karena mendapatkan nutrisi dan perawatan yang baik, serta membutuhkan waktu yang panjang. Pohon ini hanya dapat berkembang dengan sehat dan memiliki mahkota yang indah, jika akar dan batangnya juga sehat dan terawat.

Menurut teori ini, bagian akar merepresentasikan karakteristik biologis yang unik dari setiap anak untuk menerima, meregulasi, memroses, merespon, dan memahami informasi dan sensasi dari lingkungan (komponen individual differences dari pendekatan DIR), yaitu aspek yang penting dalam 
perkembangan kemampuan memusatkan atensi (Greenspan \& Greenspan, 2010). Greenspan dan Greenspan (2010) kemudian menjelaskan bahwa setiap anak memiliki perbedaan dalam cara memproses informasi, dan aspek ini membuat setiap anak menjadi seorang pembelajar yang unik. Sebagian anak sangat sensitif terhadap stimulus dari lingkungan, dan sebagian anak sangat tidak sensitive (Greenspan \& Greenspan, 2010). Perbedaan ini menjelaskan masalah dalam memproses informasi dan stimulus dari lingkungan yang membuat setiap anak menjadi unik dan memiliki karakteristik yang berbedabeda. Saat perbedaan ini menjadi signifikan, hal ini dapat menghambat perkembangan dan pembelajaran anak.

Pada anak dengan ADHD, mereka cenderung memiliki masalah pada bagian akar, yang terlihat dari masalah mereka dalam memodulasi dan memroses informasi sensoris. Hal ini membuat informasi yang masuk dari indera mereka menjadi tidak maksimal dan kurang memfasilitasi perkembangan (bagian batang; Yochmn, Parush, \& Ornoy, 2004).

Bagian batang merepresentasikan susunan dari fondasi ini (komponen developmental dari pendekatan DIR, Greenspan \& Greenspan, 2010). Bagian ini terdiri dari enam tahapan perkembangan fungsional emosional yang melibatkan kemampuan-kemampuan yang harus dikuasai anak untuk memiliki perkembangan emosional dan intelektual yang maksimal (Greenspan \& Greenspan, 2010). Greenspan dan Greenspan (2010) menyatakan bahwa kemampuankemampuan perkembangan ini merupakan hal yang esensial untuk hubungan yang memiliki empati dan penguasaan kemampuan pembelajaran. Informasi yang didapatkan dari akar, dibawa ke batang untuk memfasilitasi peningkatan tahapan perkembangan fungsional emosional
(Greenspan \& Greenspan, 2010). Hambatan pada akar seperti yang terjadi pada anak dengan ADHD, akan mengambat perkembangan fungsional emosionalnya dan tidak membuat landasan yang kuat untuk perkembangan-perkembangan lainnya, yang terlihat dari kurangnya penguasaan pada tahapan pertama, yaitu kemampuan memusatkan atensi dan regulasi diri (Greenspan \& Greenspan, 2010.

Kemudian bagian cabang merepresentasikan kualitas-kualitas anak yang muncul dari perkembangan yang baik, misalnya empati, kreativitas, berpikir logis, kepercayaan diri, kedisiplinan diri, integritas moral, kemampuan pembelajaran, kemampuan berkomunikasi, pemahaman bacaan, dan berhitung (Greenspan \& Greenspan, 2010). Performa akademis merupakan bagian cabang dari pohon ini, dan biasanya pada aspek inilah seorang guru atau orang tua pertama kali menyadari adanya masalah pada anak. Namun penting untuk menelusuri kembali di mana akar permasalahan anak dan memberikan penanganan kepada sumber masalahnya (Greenspan \& Greenspan, 2010). Pada anak dengan ADHD yang memiliki perkembangan batang yang tidak maksimal, kemampuan-kemampuan adaptifnya yang berguna di kemudian hari juga tidak akan berkembang dengan sempurna, salah satunya adalah hambatan dalam perkembangan kemampuan belajarnya (Greenspan \& Greenspan, 2010).

Sebuah pohon tidak dapat tumbuh tanpa adanya nutrisi dari air dan matahari, bagian air dan matahari masuk kepada komponen relationship dalam pendekatan DIR, yaitu interaksi dengan lingkungan yang menghasilkan pembelajaran (Greenspan \& Greenspan, 2010). Hubungan ini melibatkan pengalaman baru bagi anak dan aspek emosi dalam berinteraksi untuk meningkatkan kapasitas perkembangan 
anak dan menyesuaikan interaksi dengan karakteristik biologis yang unik pada setiap anak. Proses pembelajaran ini terjadi dalam hubungan dan interaksi yang positif, semakin positif dan berkualitas interaksi yang terjadi, semakin efisien proses pembelajaran yang terjadi.

Menurut Greenspan dan Greenspan (2009), masalah utama pada anak dengan ADHD terdapat pada modulasi dan regulasi informasi sensoris yang diterima, berdasarkan teori the learning tree, masalah ini masuk ke dalam bagian akar. Bagian akar berperan untuk mengambil informasi dari lingkungan yang akan dibawa ke batang untuk memfasilitasi perkembangan. Akan tetapi, anak dengan ADHD memiliki masalah pada bagian akar, yang membuat informasi yang diterima dan diproses menjadi tidak maksimal.

Masalah perkembangan pada bagian akar, dapat menghambat perkembangan bagian batang yaitu penguasaan enam tahapan perkembangan fungsional emosional (Greenspan \& Greenspan, 2010). Tahapan pertama dalam enam tahapan perkembangan ini adalah shared attention and regulation, di mana anak belajar untuk menerima informasi dan stimulus sensoris namun tetap dalam berada dalam keadaan tenang dan fokus sehingga proses belajar dapat terjadi (Greenspan \& Wieder, 2006). Anak dengan ADHD menunjukkan masalah dalam tahap ini, mereka akan mengalami kesulitan untuk tetap tenang dan memusatkan perhatiannya karena mereka cenderung selalu mencari stimulus sensoris dari lingkungan (sensory-seeking; Greenspan \& Wieder, 2006; Yochmn, Parush, \& Ornoy, 2004). Walaupun mereka tetap dapat melanjutkan mempelajari tahapan-tahapan selanjutnya, namun mereka cenderung gagal untuk menguasai tahapan perkembangan selanjutnya karena fondasi yang belum kuat (Greenspan \& Wieder, 2006). Perkembangan batang yang belum maksimal ini akan menghambat perkembangan mahkota dan cabangcabangnya, yaitu kemampuan memusatkan atensi dan kontrol diri sehingga memunculkan karakteristik ADHD yaitu inatensi dan hiperaktivitas/impulsivitas (Barkley, 2006).

Selain masalah dalam sensory regulation, Greenspan dan Greenspan (2009) juga mengemukakan bahwa hambatan perkembangan executive functioning juga merupakan salah satu penyebab munculnya karakteristik khas ADHD, yaitu inatensi dan impulsivitas. Fungsi eksekutif merupakan sebuah proses yang terjadi di bagian lobus frontalis di otak yang mengaktifkan, mengintegrasi, dan mengatur fungsi otak lainnya (Barkley, 2006). Fungsi eksekutif meliputi banyak area, antara lain fungsi kognitif, bahasa, motorik, dan emosional. Barkley (2006) mengemukakan bahwa 80 - $90 \%$ anak dengan ADHD memiliki defisit pada perkembangan fungsi eksekutif mereka.

Gangguan yang umumnya muncul pada anak dengan ADHD yang berhubungan dengan defisit pada fungsi eksekutif antara lain, inhibisi, kewaspadaan, working memory, dan perencanaan (Mash \& Wolfe, 2010). Anak dengan ADHD umumnya memiliki masalah dalam mengatur dan mempertahankan atensi, mengubah fokus, membuat perencanaan dan organisasi, mengingat hal-hal detil, dan menginhibisi respon yang tidak sesuai. Masalah-masalah tersebut berhubungan erat dengan hambatan pada fungsi eksekutif. Hal ini didukung oleh penelitian Brown (2005) yang menemukan enam masalah pada ADHD yang disebabkan oleh hambatan perkembangan fungsi eksekutif, yaitu dalam mengorganisasi, membuat prioritas, dan memulai pekerjaan; mempertahankan fokus dan shifting attention dalam sebuah tugas; meregulasi keadaan alert, dan 
mempertahankan tingkat usaha yang diberikan untuk mengerjakan tugas; menggunakan working memory dan mengakses memori yang sudah tersimpan (recall); serta regulasi diri.

Berdasarkan etiologi ADHD menurut pendekatan DIR/Floortime dengan menggunakan teori the learning tree ini, orang tua, terapis, atau guru dapat menggunakan prinsip DIR/floortime untuk meningkatkan tahapan perkembangannya dengan menyesuaikan cara interaksi orang tua dengan masalah anak pada bagian akar, yaitu masalah sensorisnya. Hal ini dilakukan dengan menyesuaikan interaksi caregiver dengan karakteristik biologis anak (akar) untuk meningkatkan informasi dan pembelajaran yang diterima anak, untuk kemudian dibawa ke batang untuk memfasilitasi perkembangan, dan terakhir ke cabang-cabang yang menggambarkan kemampuan pre-akademis (Greenspan \& Greenspan, 2010).

\section{Metode}

Ada dua partisipan dalam penelitian ini, yang pertama adalah seorang anak lakilaki (inisial $\mathrm{H}$ ) berusia 4 tahun 3 bulan dengan diagnosa ADHD tipe PHI. Partisipan kedua dalam penelitian ini adalah ibu $\mathrm{H}$. Ibu berusia 45 tahun dengan pendidikan S1 yang bertugas sebagai ibu rumah tangga.

Ibu dipilih menjadi partisipan kedua dalam penelitian ini karena ibu merupakan pengasuh utama $\mathrm{H}$ dan lebih sering menghabiskan waktu dengan $\mathrm{H}$ dibandingkan dengan ayah atau orang lain di rumah.

Variabel yang diteliti dalam penelitian ini adalah kemampuan anak dalam memusatkan atensi, tahapan perkembangan fungsional emosional ibu dan anak, serta kemampuan ibu dalam berinteraksi dengan anak. Alat ukur yang digunakan dalam penelitian ini antara lain tabel pencatatan observasi durasi memusatkan atensi dan frekuensi distraktibilitas yang diciptakan khusus untuk penelitian ini, Functional Emotional Assessment Scale (FEAS), serta kuesioner dan panduan wawancara Observing Child's Biological Challenge (OCBC) dan Sensory Processing - Motor Planning Questionnaire (SPMPQ).

Observasi pengukuran durasi atensi dan frekuensi distraktibilitas akan dilakukan secara bersamaan. Anak akan diberikan tiga jenis aktivitas yang berbedabeda berdasarkan tingkat ketertarikannya terhadap masing-masing aktivitas, yaitu permainan puzzle (netral), Playdoh (novel), dan Lego (familiar). diasumsikan bahwa $\mathrm{H}$ akan memiliki rentang atensi yang berbedabeda terhadap ketiga jenis aktivitas ini. Rentang atensi paling lama ditunjukkan pada permainan yang baru (playdoh), kemudian rentang atensi menurun pada aktivitas yang cukup familiar dan memiliki daya tarik yang tinggi bagi $\mathrm{H}$ (lego), dan rentang atensi paling rendah pada aktivitas yang cukup familiar dan memiliki daya tarik netral bagi $\mathrm{H}$ (lego). Setiap aktivitas mendapatkan alokasi waktu sebanyak lima menit dan akan dimainkan berturut-turut dengan urutan puzzle, playdoh, dan lego. $\mathrm{H}$ akan melakukan semua aktivitas bersama ibu namun ibu sudah diberikan pengarahan sebelumnya untuk tidak mengingatkan $\mathrm{H}$ untuk kembali fokus saat $\mathrm{H}$ mengalihkan perhatiannya.

FEAS merupakan rating scale yang dikembangkan oleh Greenspan, DeGangi, dan Wieder (2001) berdasarkan prinsip DIR untuk mengukur enam tahapan perkembangan functional emotional yang harus dikuasai anak (komponen Developmental dari pendekatan DIR). Lebih spesifiknya, skala ini digunakan untuk melihat tahapan perkembangan functional emotional ibu dan anak saat ini, dan kemampuan apa saja yang telah atau belum 
dikuasai oleh anak pada setiap tahapan perkembangan.

Terdapat dua alat ukur untuk melihat tahapan perkembangan anak dan ibu, satu untuk anak dan satu untuk ibu. Skala ini diisi oleh Pelaksana Intervensi (PI) setelah menganalisa hasil rekaman video interaksi ibu dan $\mathrm{H}$ selama situasi bermain bebas dalam durasi 20 menit pada sesi pengukuran baseline, dan sesi terakhir setelah pelaksanaan intervensi selesai. Setiap item mendapatkan skor 2 (kemampuan tersebut konsisten muncul), 1 (kemampuan tersebut muncul sekalisekali), dan 0 (kemampuan tersebut jarang atau tidak muncul sama sekali).

\section{Sensory Processing/Motor Planning} Questionnaire-Rating Scale (SPMPQ) merupakan kuesioner mengenai profil biologis anak yang dibuat oleh Greenspan dan Greenspan (2002) untuk memfasilitasi proses monitoring dari mekanisme pemrosesan sensoris dan perencanaan motorik pada anak. Data yang didapatkan dari kuesioner ini adalah gambaran profil biologis anak sebagai tambahan data mengenai kapasitas regulasi anak, termasuk sensory modulation, auditory processing, visual-spatial processing, serta motor planning.

Penelitian direncanakan akan berlangsung selama 14 sesi, yang terdiri dari 2 sesi asesmen awal untuk pengambilan baseline, 2 sesi pemberian psikoedukasi untuk ibu, 8 sesi intervensi, dan 2 sesi asesmen akhir. Setiap sesi diperkirakan akan berlangsung selama 6090 menit. Pada sesi intervensi, dua puluh menit pertama akan diawali dengan pengingat atau review dengan ibu mengenai teori pendekatan DIR/floortime yang sudah dipelajari sebelumnya serta tujuan target yang akan dicapai dalam sesi ini. Dua puluh menit selanjutnya akan diisi dengan kegiatan interaksi bermain antara ibu dan $\mathrm{H}$ menggunakan mainan yang sudah biasa dimainkan $\mathrm{H}$ di rumah, yang disebut dengan kegiatan terapi. Selama sesi terapi, PI akan berada di ruangan yang sama dengan ibu dan $\mathrm{H}$ untuk memberikan arahan dan contoh mengenai interaksi yang sesuai dengan prinsip DIR/floortime, serta melakukan coaching dengan mengawasi kegiatan yang berlangsung, memberikan masukan, dan penguatan positif terhadap usaha ibu yang sesuai dengan prinsip DIR/floortime (Greenspan \& Wieder, 2006).

Kemudian 20 menit terakhir akan digunakan untuk pemberian feedback mengenai interaksi yang sudah dilakukan serta diskusi mengenai kesulitan yang dialami. Pada setiap akhir sesi, ibu akan diberikan tugas berupa menghabiskan waktu 2x20 menit setiap harinya untuk bermain dengan $\mathrm{H}$ dengan mempraktekkan prinsip-prinsip DIR/floortime.

\section{Hasil}

Hasil penelitian ini menunjukkan adanya peningkatan dalam kemampuan memusatkan atensi yang terlihat dari peningkatan durasi memusatkan atensi per kegiatan sebanyak 3 menit satu detik dari saat baseline ke evaluasi akhir. Selain itu ditunjukkan juga adanya penurunan frekuensi distraktibilitas per kegiatan sebanyak tiga kali dari saat baseline ke evaluasi akhir. Walaupun peningkatan ini belum memenuhi kriteria keberhasilan (peningkatan dua kali lipat dari baseline), namun secara umum intervensi telah menunjukkan adanya peningkatan dalam kemampuan $\mathrm{H}$ untuk mempertahankan atensi dan fokusnya untuk melakukan sebuah kegiatan.

Selain itu, hasil penelitian ini juga menunjukkan adanya peningkatan tahapan perkembangan fungsional emosional baik pada $\mathrm{H}$ maupun pada ibu. Pada pengukuran awal, $\mathrm{H}$ dan ibu sama-sama belum menunjukkan penguasaan pada semua level dalam skala ini. Nilai skor ibu dan $\mathrm{H}$ pada saat baseline masih berada di 
bawah norma skor untuk anak usia 4 tahun (usia $H$ saat ini). Sementara pada pengukuran akhir atau saat evaluasi, $\mathrm{H}$ sudah menunjukkan penguasaan atas level I, II, dan IV. Sedangkan ibu sudah menunjukkan penguasaan pada semua level yang terukur dalam FEAS. Hasil penelitian ini membuktikan keempat hipotesa dalam penelitian ini, yaitu: (a) intervensi dengan menggunakan prinsip dan teknik DIR/floortime dapat meningkatkan kemampuan memusatkan atensi dan mempertahankan konsentrasi pada anak dengan early onset ADHD; (b) intervensi dengan menggunakan prinsip dan teknik DIR/floortime dapat meningkatkan tahapan perkembangan fungsional emosional anak dengan early onset ADHD; (c) intervensi dengan menggunakan prinsip dan teknik DIR/floortime dapat meningkatkan tahapan perkembangan fungsional emosional ibu dari anak dengan early onset ADHD; dan (d) intervensi dengan menggunakan prinsip dan teknik DIR/floortime dapat meningkatkan kemampuan ibu dalam berinteraksi terhadap anak dengan early onset ADHD.

\section{Pembahasan}

Tujuan dari penelitian ini adalah untuk melihat efektivitas penggunaan prinsip dan teknik DIR/floortime dalam meningkatkan kemampuan memusatkan atensi dan mempertahankan konsentrasi sebagai fondasi kemampuan belajar pada anak dengan early onset ADHD. Hasil penelitian menunjukkan aplikasi prinsip dan pendekatan DIR/floortime selama 8 sesi intervensi telah meningkatkan kemampuan $\mathrm{H}$ dalam memusatkan atensi dan konsentrasi terhadap kegiatan yang sedang berlangsung. Hasil tersebut terlihat dari penurunan frekuensi distraktibilitas dan peningkatan durasi memusatkan atensi pada evaluasi akhir intervensi. Sampai saat ini belum ada penelitian yang menunjukkan efektivitas penggunaan pendekatan DIR/floortime terhadap peningkatan atensi pada anak dengan ADHD, sehingga masih diperlukan dukungan dari studi-studi lain yang menerapkan prinsip DIR/floortime pada anak dengan ADHD untuk memperkuat hasil penemuan penelitian ini.

Peningkatan pada kemampuan memusatkan atensi dan konsentrasi sejalan dengan peningkatan dalam tahapan perkembangan fungsional emosional anak. Adanya peningkatan tahapan perkembangan fungsional emosional ini menunjukkan bahwa kemampuan ibu dalam menunjukkan responsivitas dan sensitivitas dalam menghadapi $\mathrm{H}$ semakin meningkat. Sensitivitas adalah kesadaran (awareness) akan keadaan anak dan usaha anak untuk berkomunikasi sebagai sinyal untuk menunjukkan kebutuhan dan keinginan anak. Kemudian, responsivitas adalah kapasitas caregiver untuk merespon sinyal anak secara konsisten dan sesuai (Department of Child and Adolescent Health and Development, World Health Organization, 2004).

Penyesuaian respon dan cara ibu dalam berinteraksi membuat $\mathrm{H}$ semakin menikmati dan merasa nyaman berinteraksi dengan ibunya. Rasa senang dan nyaman yang didapatkan $\mathrm{H}$ ketika berinteraksi dengan ibu meningkatkan penguasaan $\mathrm{H}$ dalam keterampilannya pada level I perkembangan fungsional emosional. Pada level I inilah fondasi untuk kemampuan memusatkan atensi terbentuk. Selain itu, dengan adanya peningkatan kualitas interaksi antara $\mathrm{H}$ dan $\mathrm{ibu}$, semakin meningkat pula kualitas dan kuantitas pembelajaran yang terjadi selama interaksi berlangsung. $\mathrm{H}$ semakin terlatih untuk menjaga keadaan diri yang tenang dan alert, yang membuat ia semakin mampu untuk menerima stimulus multisensoris dari 
lingkungan dan meningkatkan kemampuannya untuk memusatkan atensi terhadap stimulus sensoris yang ia terima (level I). Peningkatan kemampuannya pada level I ini menjadi landasan untuk perkembangannya pada level II dan IV yang dari hasil penelitian ini sudah mengalami peningkatan. Hal ini konsisten dengan teori Greenspan dan Greenspan (2009) mengenai The Learning Tree yang menggunakan metafora sebuah pohon untuk menjelaskan perkembangan anak. Menurut teori ini, akan lebih baik untuk menghadapi dan menangani anak sesuai dengan karakteristik profil masing-masing anak, dan bukan fokus terhadap label diagnosa yang dimiliki, seperti ADHD. Kemudian Greenspan dan Greenspan (2009) juga menekankan bahwa pentingnya menangani anak dimulai dari akar permasalahannya terlebih dahulu dan penanganan ini dapat dilakukan dengan menggunakan metode floortime, yaitu mengikuti petunjuk anak, menantang anak untuk lebih kreatif, mengembangkan perilaku dan interaksi, serta menyertakan kemampuan motorik, sensoris, dan afektif dalam berinteraksi, untuk membantu anak mengatasi masalahnya.

Menurut Greenspan dan Greenspan (2009) dan Barkley (2006), salah satu masalah utama dari anak dengan ADHD adalah adanya gangguan dalam sensory regulation, yang membuat anak dengan ADHD secara konstan mencari stimulus sensoris dan membuat mereka sulit memusatkan atensi dan mudah terdistraksi, serta menunjukkan perilaku hiperaktivitas. Dalam teori The Learning Tree, Greenspan dan Greenspan (2009) mengemukakan bahwa sensory regulation merupakan salah satu bagian dari akar pada metafora pohon yang dibutuhkan untuk mengembangkan bagian batang dan mahkota yang sehat. Bagian batang merepresentasikan kemampuan berpikir anak dan tahapan perkembangan yang harus dilewati baik secara intelektual maupun sosial (functional emotional development). Dari batang, muncul cabang-cabang mahkota, yang merepresentasikan kemampuan dasar anak untuk kemampuan pembelajaran, salah satunya kemampuan memusatkan atensi. Dengan meningkatnya kualitas interaksi ibu dan $\mathrm{H}$ (matahari dan air sebagai nutrisi yang dibutuhkan untuk sebuah pohon berkembang dengan baik) melalui penyesuaian cara interaksi ibu berdasarkan profil biologisnya (bagian akar), membantu $\mathrm{H}$ untuk mengembangkan kemampuannya dalam penguasaan keterampilanketerampilan yang dibutuhkan dalam tahapan perkembangannya (bagian batang). Kemudian perkembangan yang mulai meningkat pada bagian batang menghasilkan kemampuan dasar yang dibutuhkan untuk kemampuan pembelajaran, yaitu kemampuan dalam memusatkan atensi (mahkota).

\section{Kesimpulan}

Hasil penelitian menunjukkan bahwa penerapan prinsip DIR/Floortime efektif untuk meningkatkan kemampuan anak dengan early onset ADHD untuk memusatkan atensi dan fokus terhadap kegiatan yang sedang berlangsung. Hal ini ditunjukkan oleh (1) penurunan frekuensi ditraktibilitas yang dilakukan ketika sedang melaksanakan kegiatan, dan (2) peningkatan durasi dalam memusatkan atensi terhadap kegiatan yang sedang berlangsung.

Peningkatan

kemampuan memusatkan atensi ini diiringi dengan peningkatan kualitas interaksi antara ibu dan $\mathrm{H}$, yaitu peningkatan keterampilan yang dimiliki ibu dan anak dalam membangun hubungan dan peningkatan tahapan perkembangan fungsional emosional baik pada anak maupun ibu. Hal ini terlihat dari peningkatan skor pada 
FEAS pada anak dan ibu. Dapat disimpulkan bahwa, penggunaan prinsip dan teknik DIR/Floortime efektif untuk meningkatkan kemampuan memusatkan atensi dan mempertahankan konsentrasi pada anak dengan early onset ADHD.

Ibu dalam berinteraksi dengan $\mathrm{H}$ dengan menggunakan prinsip-prinsip DIR/floortime dan untuk meningkatkan tahapan perkembangan $\mathrm{H}$ selanjutnya: (a) ibu dapat terus melanjutkan melakukan sesi floortime di rumah dengan $\mathrm{H}$ setidaknya 20 menit dalam sehari. Akan lebih baik jika ibu mau menerapkan prinsip-prinsip DIR/floortime dalam semua aspek interaksi dengan $\mathrm{H}$; (b) melibatkan seluruh anggota keluarga, yaitu ayah dan kakak $\mathrm{H}$ untuk mempelajari dan menerapkan prinsipprinsip DIR/floortime dalam berinteraksi dengan $\mathrm{H}$; (c) untuk tetap menjaga kualitas interaksi yang saat ini sudah meningkat di antara ibu dan $\mathrm{H}$, ibu dapat melanjutkan menggunakan strategi-strategi yang sudah dipelajari dalam berinteraksi dengan $\mathrm{H}$; (d) ibu harus tetap menjaga tingkat responsivitas dan sensitivitas ketika berinteraksi dengan $\mathrm{H}$, terutama dalam membaca dan menanggapi sinyal-sinyal yang diberikan oleh $\mathrm{H}$ sebagai petunjuk keadaan dan ketertarikannya saat itu; dan (e) menggunakan permainan yang tidak menggunakan alat bantu mainan (menggunakan diri ibu, ayah, atau kakak) sebagai pilihan kegiatan bermain. Misalnya dengan bermain kuda-kudaan, kejarkejaran, membuat terowongan dengan tangan, lompat engklek.

Untuk studi-studi selanjutnya mengenai efektivitas penerapan prinsip pendekatan DIR/floortime untuk meningkatkan atensi pada anak dengan ADHD sebaiknya: (a) menggunakan interrater observer dalam melakukan pengukuran, yaitu FEAS dan alat ukur atensi; (b) memilih instrumen pengukuran yang sudah terstandardisasi dan sudah melalui uji reliabilitas dan validitas; (c) melakukan pengambilan data untuk instrumen pengukuran dengan beberapa narasumber (multiple source of data); (d) membuat buku penghubung antara pelaksana penelitian dengan orang-orang yang terlibat dalam pelaksanaan intervensi. Dalam buku ini tercatat apa saja yang sudah dilakukan pada sesi tersebut agar orang yang tidak ikut pada sesi itu dapat melanjutkan progress yang sudah dicapai untuk sesi tersebut; dan (e) memperbanyak partisipan yang terlibat dalam penelitian.

\section{Kepustakaan}

American Psychiatric Association. (2000). Diagnostic and Statistical Manual of Mental Disorders (Text Revision). Washington, DC: American Psychiatric Association.

Barkley, R.A. (2006). Attention-Deficit Hyperactivity Disorder: A Handbook for Diagnosis and Treatment. (2006). New York: Guilford Press.

Biederman,J.,. Monuteaux, M.C., Doyle, A.E., Seidman, L.J., Wilens, T.E., Ferrero, F., Morgan, C.L., \& Faraone, S.V. (2004). Impact of executive function deficits and attentiondeficit/hyperactivity disorder (ADHD) on academic outcomes in children. Journal of Consulting and Clinical Psychology, 72 (5), 757-766.

Bradway, L., \& Hill, B.A. (2004). How to Maximize Your Child's Learning Ability: A Complete Guide to choosing and Using the Best Computer Games, Activities, Learning Aids, Toys, and Tatics for Your Child. New York: Square One Publisher.

Brown, T.,E. (2005). Attention Deficit Disorder: The Unfocused Mind in Children and Adults. New Haven: Yale University press

Department of Child and Adolescent Health and Development, World Health Organization (2004). The Importance of Caregiver-Child Interactions for the Survival and Healthy development of Young 
Children. Switzerland: WHO Library Cataloguing-in-Publication Data.

Greenspan, S.I., DeGangi, G., \& Wieder, S. (2001). The Functional Emotional Assessment Scale (FEAS) for Infancy and Early Childhood: Clinical and Research Application. Bethesda:Interdisciplinary Council on Developmental and Learning Disorder (ICDL).

Greenspan, J. \& Greenspan, S. I. (2002). Functional emotional developmental questionnaire (FEDQ) for childhood: A preliminary report on the questions and their clinical meaning. Journal of Developmental and Learning Disorders, 6, 71-116.

Greenspan, S.I., \& Greenspan, J. (2009). Overcoming ADHD: Helping Your Child Become Calm, Engaged, and FocusedWithout a Pill. New York: Da Capo Press.

Greenspan, S.I., \& Greenspan, N.T. (2010). The Learning Tree: Overcoming Learning Difficulties from The Ground Up. Cambridge: Da Capo Press.

Greenspan, S.I., \& Wieder, S. (2006). Infant and Early Childhood Mental Health: A Comprehensive Developmental Approach to Assessment and Intervention. Washington DC: American Psychiatric Publishing, Inc.
Interdisciplinary Council on Developmental and Learning Disorders. (2005). Diagnostic manual for infancy and early childhood: Mental health, developmental, regulatory-sensory processing, language and learning disorders. Bethesda: Interdisciplinary Council on Developmental and Learning Disorders.

Mash, E. J., \& Wolfe, D. A. (2010). Abnormal Child Psychology (4th ed.). Belmont: Wadsworth, Cengage Learning.

Mediaindo.co.id. (2004). 5\% Anak Indonesia Alami Gangguan Pemusatan Perhatian. Ditelusuri pada 8 Januari 2013 dari http://www.mediaindo.co.id/cetak/ berita. asp?id=2004090303464924.

Schroeder, C. S., \& Gordon, B. N. (2002). Assessment and Treatment of Childhood Problems: A Clinician's Guide (2nd ed.). New York: The Guilford Press.

Yochman, A., Parush, S., Ornoy, A., (2004). Responses of preschool children with and without ADHD to sensory events in daily live. American Journal of Occupational Therapy 58(3), 294-30. 